\title{
Dentro de campo. La representación ético-estética del Holocausto a través de la película El hijo de Saúl
}

"Dentro de campo"1. The ethic-aesthetic representation of the Holocaust through the film Son of Saul 


\section{Resumen}

Este artículo orbita en torno a la representación audiovisual de uno de los capítulos más oscuros dela historia de la humanidad: el Holocausto. Partiendo de la proposición wittgensteniana de que "ética y estética son una", hemos llevado a cabo un análisis hermenéutico y semiótico de la película húngara El hijo de Saúl (Saul fia, László Nemes, 2015), tratando aspectos entre los que destacan el montaje, la imagen, el foco, el audio y el color. El objetivode este estudio es reivindicar la importancia de este filme como objeto cultural que reúne una serie de decisiones estéticas que la sitúan éticamente en el mundo y en el panorama cinematográfico, frente a otros que trivializan, estetizan o monetizan el exterminio judío a manos de los nazis. El hijo de Saúl respeta lo extraordinario del acontecimiento, e interroga al cine como medio para encontrar una vía de representación que no degenere en esa banalización del dolor. Así, llegamos a tres conclusiones. En primer lugar, que en ese constante preguntarse por las posibilidades del cine y los límites estéticos de la representación, se encuentra el comportamiento ético por parte de los cineastas. En segundo, que el espectador deberá aceptar el reto de enfrentarse a un cine alejado del modo de representación institucional (MRI) y formar parte activa del intercambio de información. Por último, que el cine como vehículo de cambio social debe servir al fortalecimiento de la democracia y contribuir a garantizar la no repetición del desastre.

\section{Palabras clave: Representación, Holocausto, cine, El hijo de Saúl}

\section{Abstract}

This paper addresses the audiovisual representation of one of the darkest chapters in the history of humanity: The Holocaust. Starting from Wittgenstein's proposition that "ethics and aesthetics are one", we developed a hermeneutic and semiotic analysis of the Hungarian film Son of Saul (Saul fia, László Nemes, 2015) and dealt with various elements like its editing, image, focus, sound and color. The main goal of this study is to claim the importance of this film as a cultural object that gathers a series of aesthetic decisions that place it ethically in the world and in the cinematographic scene, compared to others that aestheticize, trivialize or monetize the Jewish extermination by the Nazis. Son of Saul respects the extraordinary condition of the event and interrogates the cinema as medium in order to find a way of representing that does not end up banalizing the pain. In this way, we have reached three conclusions. First of all, that in this continuous wondering about the possibilities of cinema and the aesthetics limits of representation lies the ethical behavior of filmmakers. Second, that the audience shall have to accept the challenge of facing a cinema far beyond the institutional mode of representation (IMR) and become an active part in the exchange of information. And finally, that cinema as a vehicle for social change must serve to the strengthening of democracy and contribute to guarantee the no-repetition of a disaster such as the Holocaust. 


\section{Introducción}

Et d'abord la question -esthétique, éthique, psychique et politique- de savoir que faire devant ce "trou noir" (Didi-Huberman, 2015, p. 13)²

Asumir la imposibilidad de representar y convertir esa imposibilidad en una opción ética y estética (Mayorga, 2016, p. 274)

El hijo de Saúl (Saul fia, László Nemes, 2015)³ llegó a los cines de la mano de un joven director húngaro ${ }^{4}$ en 2015. Discípulo de Bela Tarr, László Nemes estrenó su primer largometraje en diciembre, y meses después, arrasaba por el circuito de festivales europeos y estadounidenses, en un ascenso meteórico que culminaría con el premio de la Academia a Mejor Película Extranjera. En Cannes, el veterano filósofo, periodista y cineasta Claude Lanzmann ${ }^{5}$-responsable de alumbrar el documental Shoah treinta años antes- afirmó que "il (Nemes) a fait un film dont je ne dirai jamais aucun mal. Ce Fils de Saul mérite une place au palmarès"6 (citado en Blottière, 2015, n.p.). Poco después, Georges Didi-Huberman publicaba Sortir du noir, un breve ensayo en torno a El hijo de Saúl en forma de epístola dirigida a su director. En él, el académico revisita la compleja tensión que existe entre el Holocausto y su representación, y justifica el elogio a la película de Nemes reivindicando la valentía y el cuidado con los que el húngaro se atrevió a retratar un evento por muchos considerado imposible de imaginar.

En un episodio inédito hasta entonces, ambos pensadores, Lanzmann y Didi-Huberman, habían encontrado en la película húngara un lugar común en lo que a la representación del Holocausto respecta. Al igual que ocurre con otras películas que tratan la barbarie nazi y además son contadas desde los "márgenes" del canon cinematográfico ${ }^{8}$-la misma Shoah, Historia(s) del cine

\footnotetext{
2 “Y, ante todo, la cuestión -estética, ética, psíquica y política- de saber qué hacer frente a este "agujero negro" (Didi-Huberman, p. 13, 2015). Traducción propia.

${ }^{3}$ El hijo de Saúl es una producción húngara que narra la historia de Saúl, un miembro del Sonderkommando -literalmente "comando especial", eran generalmente judíos encargados de guiar a los prisioneros recién llegados al campo de exterminio hacia las cámaras de gas, los desvestían y más tarde recolectaban la ropa y sacaban los cadáveres de las cámaras- de Auschwitz, en su búsqueda frenética de un rabino que oficie una ceremonia funeral para un niño muerto del que dice ser padre.
}

${ }^{4}$ László Nemes (Budapest, 1977) había dirigido previamente un cortometraje titulado Con un poco de paciencia (Türelem, László Nemes, 2007). En él, encontramos un claro antecedente estético de El hijo de Saúl (reconocemos al director con aspectos como el interés por la temática Holocausto-Segunda Guerra Mundial, el empleo de largos planos secuencia o la gran importancia del audio en fuera de campo).

${ }^{5}$ Claude Lanzmann fue un cineasta y periodista francés que defendió hasta su muerte un recuerdo del Holocausto libre de archivo, levantado exclusivamente a través de las palabras de quienes experimentaron el terror nazi. La única vía ética de plasmar la historia del exterminio judío consistía en otorgar total protagonismo al testimonio de las víctimas y nunca recurrir a la ficción o al archivo.

6 “Nemes ha hecho una película de la que nunca diré nada malo. El Hijo de Saúl merece un lugar en el palmarés". Traducción propia.

${ }^{7}$ Georges Didi-Huberman es un académico francés que reivindica la necesidad de prestar atención al contenido archivístico audiovisual y fotográfico sobre el Holocausto, ensalzando su papel testimonial en la misma medida que las palabras de quienes sobrevivieron al horror. Lanzmann y Didi-Huberman representan a dos corrientes fundamentales en el debate en torno a la representación del Holocausto.

${ }^{8}$ Seguiremos desarrollando esta idea más adelante, pero podríamos identificar ese canon hegemónico con el cine hollywoodiense, con películas como La lista de Schindler como su máximo exponente Exodus, The reader, La casa de la esperanza, Malditos bastar- 
(Histoire(s) du cinéma, Jean-Luc Godard, 1988-1998) o Images of the World and the Inscription of War (Bilder der Welt und Inschrift des Krieges, Harun Farocki, 1989) y Respite (Aufschub, Harun Farocki, 2007), cada una con sus particularidades- ver El hijo de Saúl supone una experiencia que obliga al espectador a participar del dantesco espectáculo al que está asistiendo para decodificar la información que va recibiendo. En una entrevista para El cine de la 2 con motivo de la promoción de la cinta en España, Nemes puso de manifiesto que la intención era "empujar al espectador a que fuerce su imaginación, restringiéndole el punto de vista y acercándolo a un solo individuo, teniendo un fondo desenfocado, fuera de cuadro, trabajando cuidadosamente el diseño de sonido" (Nemes, 2015).

Nemes emplea los recursos cinematográficos a su disposición, como el sonido, la composición o el montaje para evocar en su diégesis las mismas "reglas de juego" ${ }^{9}$ que regían en Auschwitz. ¿Cómo introducir un plano mínimamente pausado o un sonido limpio donde todo era frenesí? La cámara queda subordinada a la historia contada en la película, y la escasez de cortes en las secuencias aumenta la claustrofobia por sabernos presos de un plano sin apenas profundidad de campo. Este texto tiene como objetivo hacer emerger a la superficie las particularidades técnicas, semánticas y contextuales de El hijo de Saúl para analizarlas y entender por qué la producción húngara volvió a poner sobre la mesa la controvertida relación entre el Holocausto y la posibilidad de su representación.

\section{Hacia una representación ético-estética de Auschwitz}

Escribe Rodríguez Serrano (2015) que "hay algo que Lanzmann y sus seguidores quizá no se han planteado nunca. Quizá nosotros, la tercera y cuarta generación después de Auschwitz, también deseamos seguir hablando de lo que ocurrió en los campos. Pero para hacerlo, y a costa de la tradición, primero tenemos que inventar unas nuevas normas del juego, un nuevo lenguaje" (p. 27). El hijo de Saúl acumula recursos cinematográficos de los que la historia requiere para alcanzar su cometido ético-estético, al igual que Brecht necesitaba para sus poemas de un ritmo que tradujera "la respiración jadeante del que corre" (Didi-Huberman, 2008, p.174). No en vano, el ritmo de la pieza será fundamental a la hora de describirla. Parece conveniente, sabido esto, acudir a las enseñanzas del filósofo Ludwig Wittgenstein, que escribió en la proposición 6.421 de su TractatusLogico-Philosophicus (1921) que "ética y estética son una y la misma cosa". Cuando a principios de los años 30 uno de los alumnos de Wittgenstein, Rush Rhees, preguntó a su maestro si tenía una teoría de la decadencia, este contestó afirmando que, en lugar de decir qué es decadencia, podía describir diferentes cosas llamadas decadentes. En el caso que nos ocupa, donde el "qué" es tan sumamente problemático (el Holocausto), podemos acceder a él a través del "cómo". Para describir Auschwitz y la historia del Sonderkommando y sus integrantes, Nemes recurre a elementos formales y semánticos que acaban por configurar una narrativa respetuosa a la vez que atrevida, delicada a la vez que violenta y, por supuesto, bella a la vez que terrible. No 
en vano, Simone de Beauvoir manifestó, refiriéndose a Shoah de Lanzmann, que "nunca jamás hubiera podido imaginar semejante alianza entre el horror y la belleza", aunque siempre dejando claro que "la segunda no es capaz de ocultar al primero, no se trata de esteticismo" (citado en Lanzmann, 2003, p. 10). Para Jaime Pena (2020),

Shoah es la consecuencia de cuatro décadas [1945-1985] de debates en torno a cómo representar el Holocausto. Desde la crítica cinematográfica, pero también desde la filosofía, se va delimitando un camino que se traduce en la adopción prioritaria de una serie de elementos expresivos y fórmulas narrativas (p. 32).

El hijo de Saúl, por su parte, constituye una constante búsqueda de la manera de trasladar el horror del campo sin recurrir a la mímesis, ni a la estetización -eso que Beauvoir denomina "esteticismo"-. Evocar mediante la imagen sensaciones en el espectador, invocando energías oscuras que siguen latiendo en la historia y dejando que su imaginación complete el proceso. En palabras de Nemes, "el poder de la imaginación es moralmente muy importante porque no podemos recrear el horror, solo podemos sugerirlo" (citado en Martínez, 2016, n.p.). Esta es la gran diferencia entre El hijo de Saúl y otras películas como La lista de Schindler (Schindler's List, Steven Spielberg, 1993), en la que Spielberg quiso representar el Holocausto sirviéndose de los instrumentos y los recursos estéticos que ofrece el cine clásico -blanco y negro, banda sonora, guion cerrado con picos dramáticos actuados- olvidando a veces la ética, y elaborando, a nivel de contenido, una interpretación particular de cómo había sido el desastre que en última instancia constituye una historia de supervivencia, de esperanza, de excepcionalidad. Una historia artificial y edulcorada que tiende a relegar a un segundo plano a los millones de víctimas a las que ningún Schindler salvó.

\subsection{El camino hasta llegar a El hijo de Saúl pasa por Shoah y por Godard}

Godard rechazó las reglas canónicas y "montó"10 compulsivamente, con la sospecha de que la única forma de trasladar al espectador el horror era a través de la concatenación de imágenes y de que, de entre los intervalos y los mecanismos de sístole y diástole, emergería el verdadero significado. Lanzmann dejó claro que su Shoah no es una película sobre los supervivientes, sino sobre la muerte; la muerte en los campos de exterminio y en las cámaras de gas (Cabrerizo y Etxeberría, 2010, n.p.). El francés deseó oponer el filme a la ausencia, a la borradura que habían llevado a cabo los nazis en los campos de exterminio, creando para ello una atmósfera única a partir de esa tensión constante entre la voz en off y las imágenes de paisajes, la puesta en escena, las entrevistas, y una hercúlea tarea de documentación que llevó al realizador por todo el mundo.

En todo caso, no tratamos de afirmar que El hijo de Saúl supone la síntesis perfecta, la solución definitiva al problema de la representación del exterminio, puesto que todas las producciones que la han precedido han sido necesarias para ir definiendo el ángulo a partir del cual miramos o deberíamos mirar el Holocausto. El hijo de Saúl es el resultado de un proceso de trabajo duro que logra "sacar la negrura de su abstracción", como escribió Didi-Huberman (2015, p. 16), y con- 
cretarla, llegando a donde pocos han llegado y trasladando al espectador a un "aquí y ahora" terrorífico. A fuerza de sugerencias, mostraciones veladas e insinuaciones, el interlocutor-espectador forma parte activa del diálogo, completa el significado, al igual que ocurre en las Historia(s) de Godard.

\section{3. ¿Por qué confiar al cine la tarea de representar el Holocausto?}

El escritor español Jorge Semprún, superviviente de Buchenwald, creía que la única forma de enfrentarse al trauma era a través del arte, frente a otros, entre los que destacan el filósofo Theodor W. Adorno y su certeza de que, después de Auschwitz, escribir un poema era un acto de barbarie, o Lanzmann, que consideró que estetizar el universo concentracionario era sinónimo de trivializarlo. El cine clásico impuesto por Hollywood durante los años anteriores y posteriores a la Segunda Guerra Mundial ${ }^{11}$ se empeñó en esconder la cámara, en otorgarle un papel secundario frente a lo que estaba sucediendo en el plano. En palabras de Sánchez Biosca, la manera de significar que había alumbrado el cine estadounidense -el canon que ha ido incorporando amables y discretas modificaciones para asegurar su permanencia a la cabeza de la industria aún hoy- evitaba la "descomposición del significante" y la "vivencia angustiosa del lenguaje". Por ello, el autor afirma que, "podría decirse que este cine, el clásico, lucha por desconocer las fracturas decisivas de la Modernidad, y pugna igualmente por esconder la máquina y sus efectos tras la fábrica de relatos" (1991, p. 121).

Aunque este paradigma ha ido transformándose y adoptando diferentes formas, las producciones actuales siguen sin exprimir al máximo - por regla general- los recursos que solo el cine puede ofrecer como medio y que podrían enriquecerlas. En unos versos profundamente reveladores de sus Historia(s), Godard susurra “y si George Stevens/ no hubiera sido el primero en usar/ la primera película/ dieciséis color/ en Auschwitz y Ravensbrück/ quizás jamás/la felicidad de Elizabeth Taylor/ hubiera encontrado/ un lugar al sol" (Godard, 2007, pp. 79-80). La dialéctica de estos versos es palpable, más aún tras observar el montaje del suizo, del que se extrae que "la ficción de felicidad que envuelve a Montgomery Clift y Elizabeth Taylor solo aparece en el contrapunto de una tal desolación del pasado" (Didi-Huberman, 2004, p.247).

De nuevo, se trata de emplear la técnica para crear formas distintas de narrar, de plantear otras aproximaciones ético-estéticas a las imágenes y a las historias, con la intención de que creador y espectador ${ }^{12}$ establezcan una conversación en la que no todo quede dicho de primeras. El cine es capaz de reformularse constantemente, pero necesita de una mente ambiciosa que se atreva a jugar con él, que le proponga retos y lo lleve hasta las últimas consecuencias. Y, por supuesto, de interlocutores intrépidos que se atrevan a formar parte del intercambio, que deseen familiarizarse con el sistema de poleas en lugar de limitarse a perderse en la exuberancia del decorado.

\footnotetext{
${ }^{11}$ En este sentido, esa "belleza" artificial que estetiza se comprende como un velo que esconde dolosamente la realidad a la que necesitamos hacer frente. Películas realizadas por europeos inmediatamente después de 1945 como Un americano en París (An American in Paris, Vicente Minelli, 1951), El hombre tranquilo (The Quiet Man, John Ford, 1952) o Vacaciones en Roma (Roman Holiday, William Wyler, 1953), nos introducen en una Europa repuesta del dolor causado por la Segunda Guerra Mundial, y, por tanto, falsa. 
Es por esto que parece conveniente preguntarnos qué es eso que hace especial al cine, qué lo diferencia de otras formas que la especie humana ha ido hallando a lo largo de los milenios para contar sus historias. Crespo (2008) lo retrata así:

Artefacto al que dirigir, al que apuntar hacia la escena. En su funcionamiento íntimo, tiene la capacidad de sorprender la realidad, de ofrecernos lo inesperado; la capacidad, en definitiva, de ser estética aún sin proponérselo, o al menos, de ir más allá ${ }^{13}$ de las intenciones verbales humanas que la rodean (p. 19).

Cuando Wittgenstein habla en sus Lecciones y conversaciones sobre estética, psicología y creencia religiosa sobre lo que no se puede describir, se refiere a ese "ir más allá" que entraña el cine. "Puedo hacer un gesto, pero eso es todo" (Wittgenstein, 1992, p. 109). Ante un hecho tan excepcional como es el Holocausto se espera de los creadores que honren el pacto ético-estético contraído con las víctimas, buscando vías alternativas, excepcionales, de contar su historia. Puede que no quepa la mera descripción ante un desastre de tal magnitud, sino que haya que trascenderla, encontrar fórmulas mediante las que proveer al interlocutor de una experiencia que sea igualmente indescriptible. Por eso, Wittgenstein afirmaba que las "cuestiones estéticas no tienen nada que ver con experimentos psicológicos; se responden de otro modo completamente distinto" (Wittgenstein, 1992, p. 84). Sin embargo, en esta constante búsqueda de maneras de representar el exterminio, podemos encontrar motivos visuales que nos resulten familiares.

\section{El terror de los campos se descompone en fórmulas ya conocidas}

A través del análisis de distintas obras y documentos que versan sobre el genocidio y la barbarie, Burucúa y Kwiatkowski extraen en su Cómo sucedieron estas cosas tres "motivos literarios" o "metáforas complejas que definen y representan hechos (las masacres reales) mediante la indicación de otros hechos" (Burucúa y Kwiatkowski, 2015, p. 71) y que se van repitiendo en los relatos: la fórmula del martirio, la cinegética y la infernal. La primera de ellas pone el énfasis "en la inocencia, en la constancia, el destacado papel de la violencia en los perpetradores o la emoción enaltecedora de las víctimas, y, finalmente, el imperativo de la memoria de estas" (Burucúa y Kwiatkowski, 2015, p. 129). En segundo lugar, la cinegética radica en reducir el estatuto de la víctima de hombre o mujer al de animal, de manera que pasan a ser 'otros' deshumanizados y animalizados de modo condenatorio, incluso acusados de contaminar al "nosotros'" (BurucúayKwiatkowski, 2015, p. 81). La última de las fórmulas puede ser ilustrada con la identificación que las etnias deportadas a los campos de concentración establecían entre estos y el infierno o el apocalipsis (Burucúa y Kwiatkowski, 2015, p. 174). No en vano, en los manuscritos hallados ${ }^{14}$ en Auschwitz que el preso Zalmen Gradowski escribió clandestinamente y después enterró, podemos leer: “iNo puedo siquiera malgastar una lágrima! Porque vivo en un inferno de muerte, donde es imposible abarcar mi enorme pérdida" (Gradowski, 1988, p. 584).

\footnotetext{
${ }^{13}$ Cursiva propia.

${ }^{14}$ Estos manuscritos, recientemente hallados y conocidos como los Scrolls of Auschwitz detallaban la vida en el campo, así como el dolor y las penurias de los prisioneros.
} 


\subsection{Animales, mártires y una escena infernal}

Ciertamente, podemos encontrar las fórmulas antes mencionadas en las palabras de las víctimas, en los fotogramas de una película, en los dibujos de un cómic... Burucúa y Kwiatkowski las describen como "un conjunto de dispositivos culturales que han sido conformados históricamente $y$, al mismo tiempo, gozan de cierta estabilidad, de modo que son fácilmente reconocibles por el lector o el espectador" (Burucúa y Kwiatkowski, 2015, p. 46).

Las tres analogías forman parte de la representación del Holocausto. Tradicionalmente, se nos ha mostrado los campos de concentración como lugares infernales, a los judíos hacinados, golpeados y cazados, un pueblo mártir, inocente frente a la bestialidad de los nazis. Y las tres pueden ser localizadas en El hijo de Saúl, desde la primera secuencia, en la que se nos presenta al protagonista guiando a un grupo de deportados recién llegados al campo, como si de un pastor orientando a un rebaño se tratase, sin rostro, sin voz y en un redil cuyas cercas son los brazos de los miembros del Sonderkommando (Imagen 1). Pero no debemos olvidar que los hombres del "comando especial" no tenían garantías de supervivencia muy superiores a las de quienes conducían a la muerte. Ganado útil, pero ganado, al fin y al cabo.

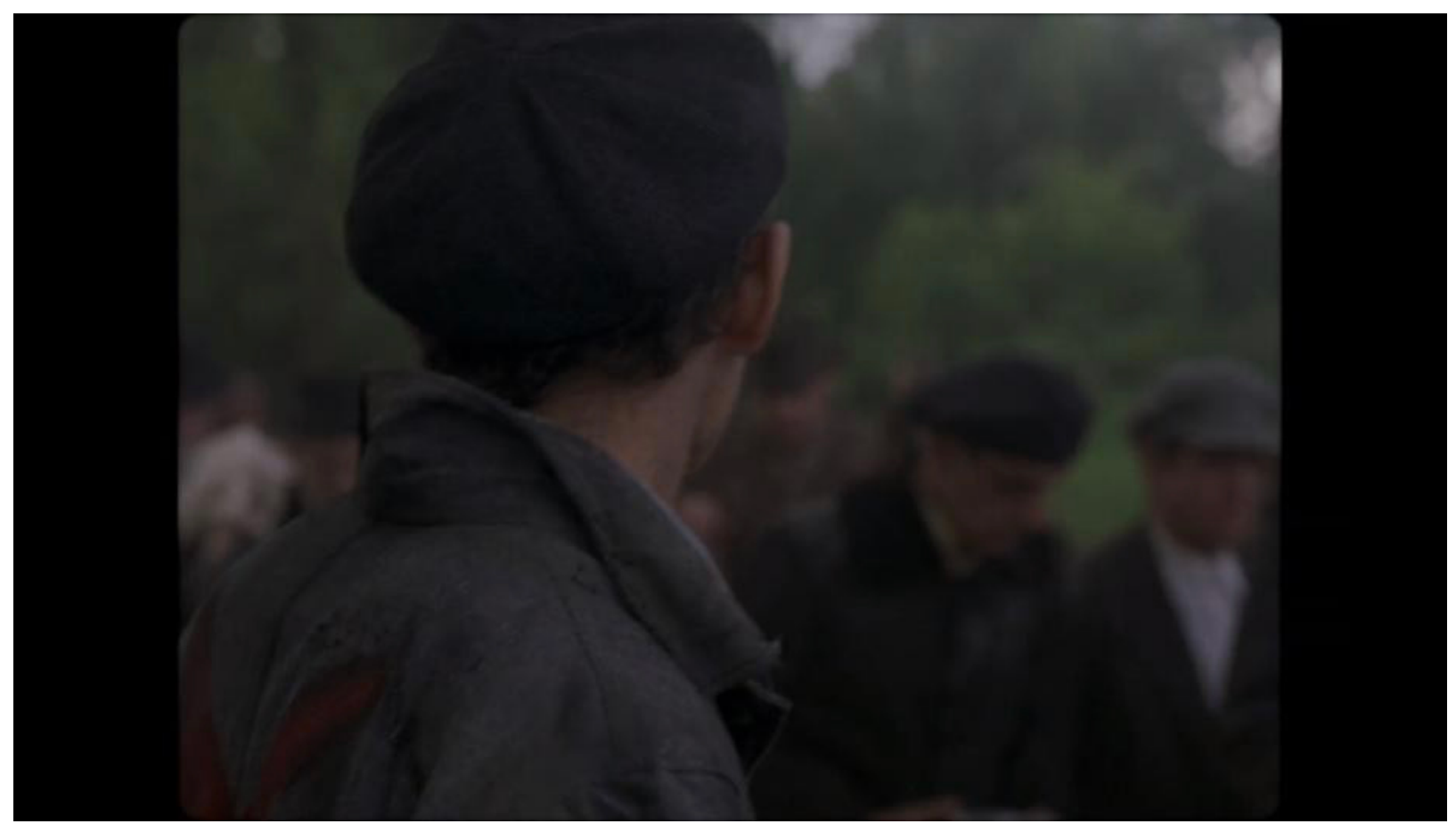

Imagen 1. Saúl recibe a los deportados recién llegados al campo (cinegética)

En segundo lugar, encontramos en el niño anónimo, cuya muerte supone el detonante de la trama, la figura del mártir y del santo inocente, un haz de luz que deslumbra momentáneamente a Saúl y a sus compañeros. Su partida los devuelve a la oscuridad, pero al mismo tiempo otorga un propósito al protagonista, una razón para vivir un día más en el campo.

Desde el comienzo del culto a los santos inocentes y cada vez más en representaciones posteriores, se destaca la inocencia radical de los niños-víctima, su debilidad y su completo estado de indefensión [...] La masacre del inocente se convierte en escenario de todas las representaciones figurativas de la desesperación y del desgarramiento emocional sin límites (Burucúa y Kwiatkowski, 2015, p. 102). 
Recién comenzada la película, el supuesto hijo de Saúl muere dos veces. La cámara de gas no acaba con su vida. Los hombres del Sonderkommando, afanados en su tarea de borrar todo rastro de muerte de las paredes, los techos y los suelos de la estancia, observan al niño con una mezcla de respeto religioso y compasión. Sobrevivir al Zyclon B parece un milagro. ¿Despide el cuerpo del infante un leve fulgor blanquecino o es pura sugestión del espectador? En todo caso, pronto se acerca un médico nazi a apagar la luz del joven mártir que intenta respirar ante la mirada atenta de Saúl (Imagen 2). Leemos en este breve pasaje la trama fundamental del filme de Nemes: "El martirio implica que los vivos siguen adelante en compañía de los muertos martirizados, cuya memoria impulsa el activismo continuado y la supervivencia emocional de los que siguen vivos". (Burucúa y Kwiatkowski, 2015, p. 130). Enterrar al niño-mártir se convierte en una obsesión que invade el rostro de Saúl y se manifiesta en sus actos suicidas. Es el asidero que impide que el protagonista se precipite a esa negrura en la que huele a grasa, carbón y humo. Sin embargo, Saúl ya no teme al infierno del Bosco, flamígero, bíblico (Burucúa y Kwiatkowski, 2015, p. 175) (Imagen 3), ni le preocupa su cuerpo, perecedero y contingente, expuesto a las llamas y continuamente zarandeado y maltratado.

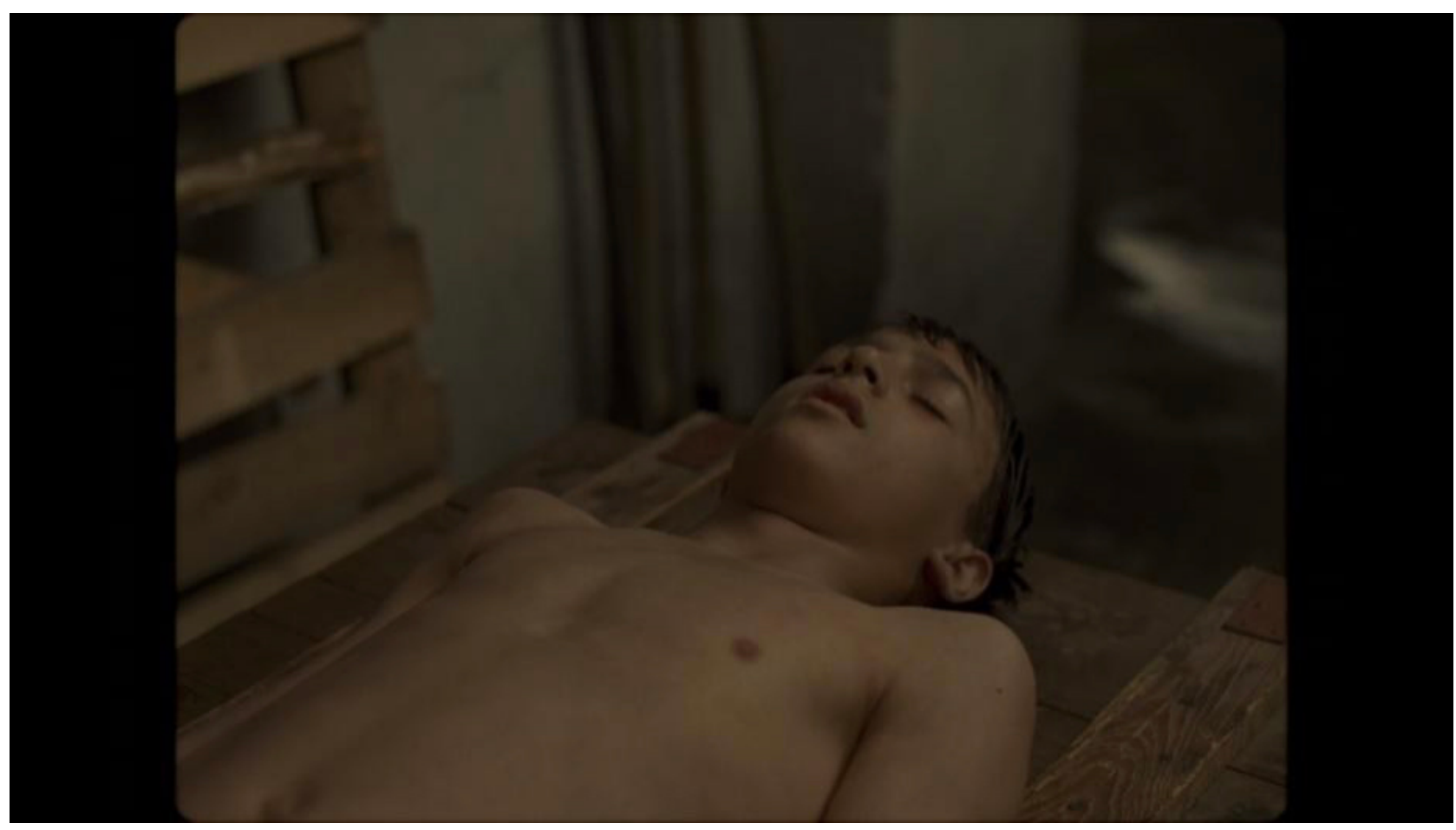

Imagen 2. El “hijo" de Saúl (martirio)

Las tres fórmulas se van sucediendo ante los ojos de Saúl, que articula y vertebra el filme, pero a él no parecen importarle. A continuación, nos detendremos en el personaje, en su psicología, en la relación que mantiene con la cámara y en todo aquello que lo diferencia de otros protagonistas de narrativas desplegadas en el marco del Holocausto.

\section{La maestría de Nemes o cómo mostrar a Saúl}

Conforme se van sucediendo los años, aparecen nuevas formas de mirar al pasado, alejadas del discurso predominante, que dedican sus esfuerzos a captar la vida en su conjunto, y no significa- 


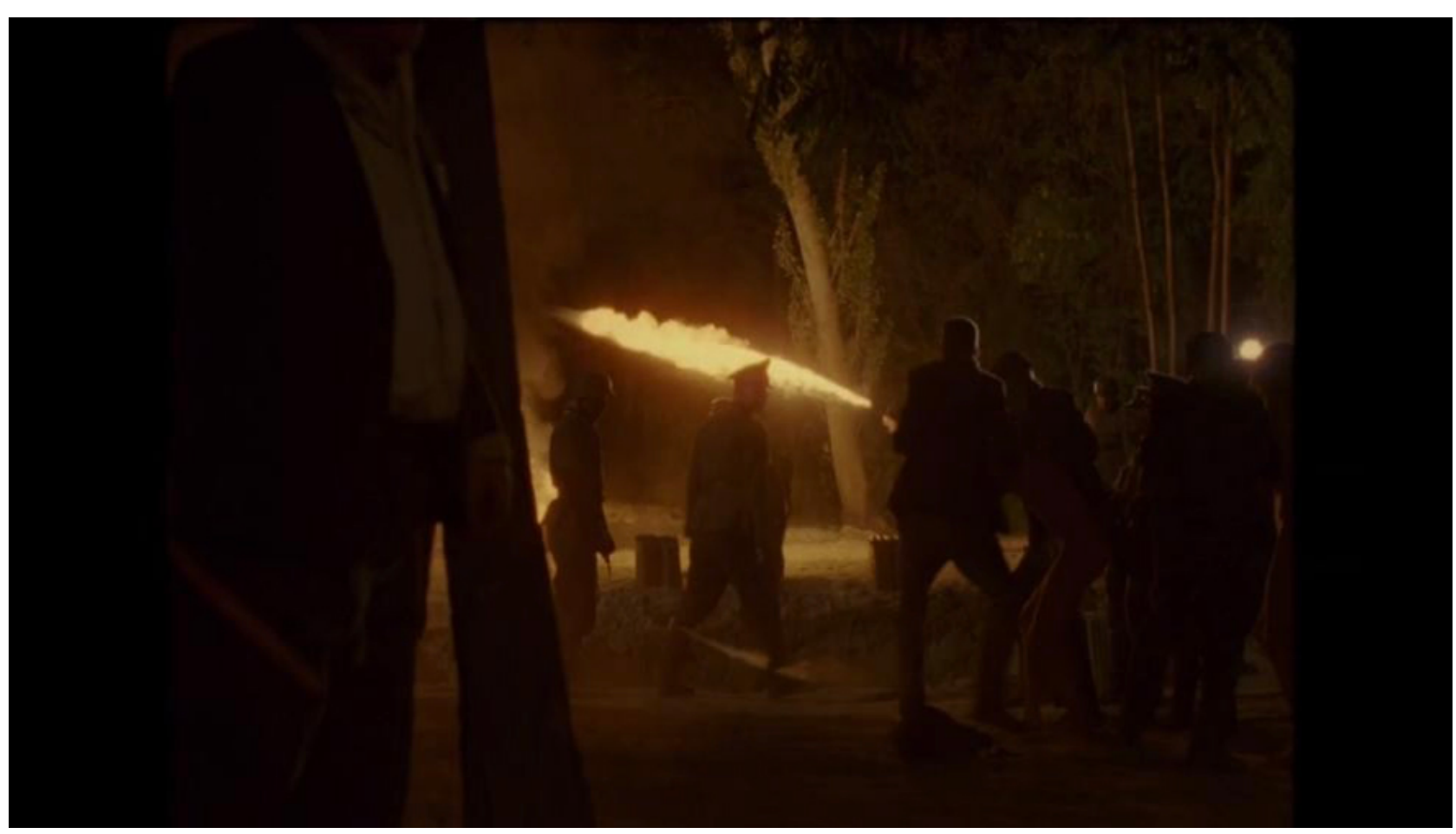

Imagen 3. El infierno es Auschwitz (infernal)

dos aislados. En su poema Preguntas de un obrero que lee, Bertolt Brecht se plantea:

¿Quién construyó Tebas, la de las siete Puertas? En los libros aparecen

los nombres de los reyes

¿Arrastraron los reyes los bloques de piedra? [...]

Tantas historias.

Tantas preguntas. (Brecht, 1998, p. 24)

En esta línea, Ginzburg ${ }^{15}$ escribe en el prefacio de su obra El queso y los gusanos que "la escasez de testimonios sobre los comportamientos y actitudes de las clases subalternas del pasado es fundamentalmente el primer obstáculo, aunque no el único, con que tropiezan las investigaciones históricas" (Ginzburg, [1976] 2001, p. 7). En otras palabras, si hablamos del Holocausto, la mayoría de los discursos hegemónicos nos trasladan la historia de aquella mujer judía que se salvó o de aquel alemán nazi que rechazó el antisemitismo, pero no suelen retratar lo que en ese lugar y en ese momento era considerado como "normal" en el sentido de que ocurría reiterada e inexorablemente: la muerte misma.

Películas como La vida es bella (La vita è bella, Roberto Benigni,1997), El tren de la vida (Train de vie, Radu Mihaileanu, 1998) -ambas pensadas en clave de tragicomedia, lo que inevitablemente hizo que saltaran las alarmas- o La lista de Schindler, cuentan historias de supervivencia, es decir, giran en torno a excepciones. Como dijo Lanzmann en una entrevista en 2010, refiriéndose a la "escena de las duchas"16 en la película de Spielberg, "para la mayoría de los judíos fue al

\footnotetext{
${ }^{15}$ Carlo Ginzburg es un historiador italiano considerado el padre de la Microhistoria, una corriente que persigue, entre otras cosas, poner el foco en la gente corriente que habitó un tiempo y un espacio y extraer de ella información acerca de sus costumbres y sus formas de vida.

${ }^{16}$ En esta escena, ampliamente discutida, Spielberg muestra a un grupo de mujeres adentrándose en lo que parece ser una cámara de gas, pero, finalmente, de los conductos situados en el techo, sale agua.
} 
contrario, salió gas por donde esperaban que saliera agua" (citado en Ridao, 2010, n.p.). Saúl no es una excepción, sino uno más, una historia perdida que alguien quiso reivindicar, un hombre sin rostro que almacenaba preguntas que por fin alguien se dignó a responder. El investigador Ernst Van Alphen (1998) escribió que "el Holocausto no se hace presente por medio de un acto verificable del lenguaje, esto es, como un relato mediado, como el contenido verdadero o falso de un acto semejante, sino que se hace presente en calidad de efecto performativo" (p.9).

El hijo de Saúl no pretende ser una copia del Holocausto (mímesis), y mucho menos extraer belleza del sufrimiento humano (estetización), sino que se trata de una inmersión salvaje (en el sentido del término inglés "raw") en un momento histórico que fue igual de salvaje. Afrontar los campos de concentración y exterminio desde una perspectiva fílmica clásica disminuye inevitablemente el impacto porque la persona encargada de representarlos nunca deja de intentar convertirlos en una entidad "racional" - ¿será que en el fondo aún no lo llegamos a entender?-. Elaboran una suerte de imitación regida por nuevas pautas destinadas a poner orden donde todo era caos y ofrecer al espectador una experiencia intelectual. Pero puede que obras como Shoah o El hijo de Saúl no deban ser interiorizadas y comprendidas mediante la razón.

\subsection{Las "reglas de juego"}

Cuando Nemes nos obliga a pegarnos a los talones de un miembro del Sonderkommando, quiere hacer un retrato de un hombre cualquiera en el campo, no un despliegue de medios cinematográfico. Se trata de dar con los recursos que el cine ofrece para trasladar el horror de la pantalla al corazón del espectador, encontrar el ángulo de la cámara que constituya la puerta de entrada a la locura del campo. En este sentido,

la elección de un ratio cuadrado y un objetivo de $40 \mathrm{~mm}$ reduce considerablemente el campo de visión, aprisionando el rostro de Saúl y dejando el exterminio como un mero trasfondo que el espectador solo puede desentrañar gracias a unas imprecisas y difusas imágenes, pero sobre todo a través de unos sonidos que desencadenan algo en el espectador, la necesidad de ver más, pese a que le resulte imposible" (Pena, 2020, p.137).

La película en sí es un efecto performativo (Van Alphen, 1998, p. 9) y Saúl un catalizador, un puente de acceso a esta realidad tan terrorífica que a veces se confunde con su referente. Para entender el filme debemos entender a su protagonista, porque todo gira en torno a él y al mismo tiempo no es nadie más allá de un ser anónimo consciente de que morirá tarde o temprano. "El dispositivo cinematográfico se mueve cerca de la cabeza o del cuerpo de Saúl, le sigue por la espalda o se despega levemente de sus propios pasos. La limitación del encuadre reduce el campo de visión, lo cual impide la mostración directa y expeditiva del terrible genocidio que habita en su entorno más próximo". (Ferrando García y Gómez Tarín, 2018, p. 303).

Así, parece innegable, por un lado, que la experiencia visual que es la película representa el estado mental del protagonista y, por otro, que las pautas audiovisuales de la diégesis se articulan en torno a él. Esto quiere decir que, en el filme, Saúl constituye el principio y el fin de las "reglas de juego" del campo, un guardián invisible que discrimina lo que se muestra y lo que no, hacia dónde dirigir la cámara y, por ende, la mirada del espectador. La forma en que la cámara orbita a 


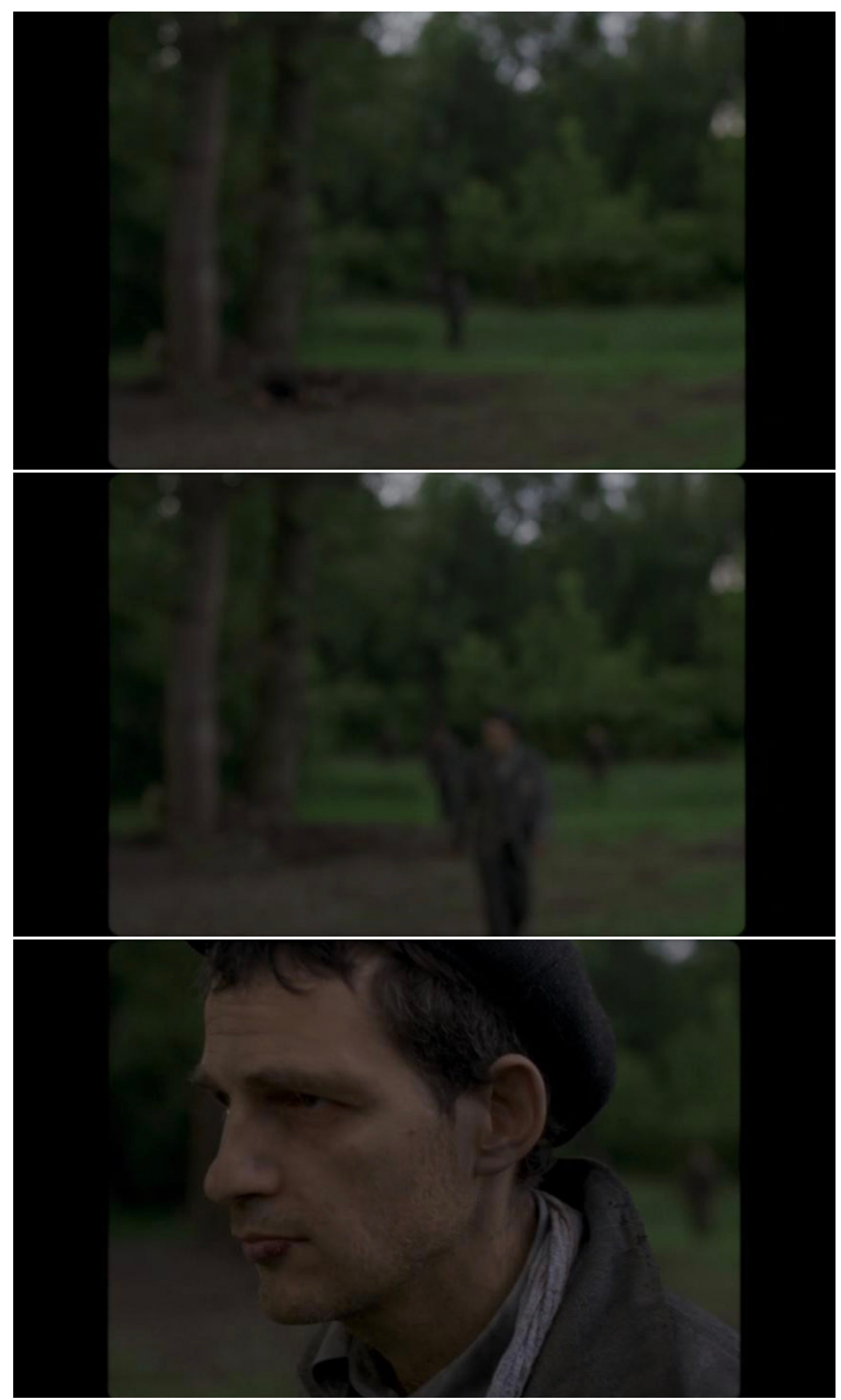

Imagen 4. Saúl se va haciendo nítido en un plano sin apenas profundidad de campo.

Claustrofobia en el espacio abierto 
su alrededor, sin separarse nunca demasiado de él, atenta a sus movimientos en todo momento, completa el significado de Saúl. De hecho, en los primeros minutos, que sintetizan a la perfección el carácter ético-estético de la película, observamos cómo la lente espera al protagonista para alcanzar la nitidez (Imagen $4^{17}$ ). Este fenómeno contribuye a que el personaje gane definición -en todos los sentidos-, frente al caos en el que se encuentra inmerso y supone la manera perfecta de captar sus miradas, sus silencios, sus gestos.

Se trata de no caer en esa estetización que banaliza, emplear todos los recursos que el cine ofrece para definir Auschwitz-Birkenau sin eufemismo alguno. La tarea, que podría equipararse a apuntar con una cámara al corazón del horror, es arriesgada y requiere de un "manual de instrucciones" que ha de ser respetado en todo momento. El hijo de Saúl es la prueba de que la mayoría de cineastas han preferido maquillar el Holocausto a mostrarlo como lo que realmente es: una herida abierta, una enfermedad de la que Europa no se ha recuperado aún. Y es necesario atender a sus síntomas, que no son más que las reglas de representación seguidas a rajatabla en la película, como una suerte de dogma inquebrantable.

\subsubsection{La imagen nunca se detiene}

Trabajábamos tan rápido como podíamos porque todos éramos profesionales ¿Qué cómo lo hacíamos? Se cortaba así, aquí... allí... y allá... De este lado... De este otro lado... Y se acabó [...] No había ni un segundo que perder; el otro grupo esperaba ya fuera para pasar por el mismo proceso (Lanzmann, 2003, p. 120).

Son las palabras de Abraham Bomba, el peluquero deportado a Treblinka que fue entrevistado por Lanzmann para Shoah ${ }^{18}$. Durante la conversación con el director francés, cuenta que su tarea consistía en cortar el pelo de las mujeres minutos antes de que estas fueran enviadas a su muerte en las cámaras de gas. Sus palabras, la manera de gesticular y su discurso roto, desprenden la urgencia, el terror de aquellos momentos, igual que lo hacen las del antiguo Sonderkommando Müller al describir la llegada de un transporte de prisioneros al campo de exterminio: "Llegaron deslumbrados y a la carrera. Molidos a palos. El que no corría lo suficientemente rápido era fusilado por los SS" (Lanzmann, 2003, p. 169). Detener la imagen cuando se pretende mostrar estas circunstancias supondría el más flagrante intento de borrar el terror, hacerlo más digerible para el espectador. Como escribió Didi-Huberman (2015) "en un espacio en el que el horror es obsidional, la única mirada posible es una mirada de duración corta y de distancia corta" (p.29).

\subsubsection{El background siempre aparece fuera de foco}

Durante toda la película se mantiene una tensión constante entre el primer plano y el fondo. El primero siempre se mantiene en foco y alberga en su seno todas las imágenes relacionadas con la misión de Saúl: enterrar al niño. Mientras tanto, el segundo nunca aparece enfocado, como si viéramos lo que va sucediendo a través de la visión periférica del protagonista. Se trata de forzar al espectador a que imagine, a que intuya el horror, y a que sienta en cierta manera la alienación

\footnotetext{
${ }^{17}$ Vemos en El hijo de Saúl una introducción del personaje de Saúl inspirada en la presentación de la protagonista de Türelem.

${ }^{18}$ En 2003, Claude Lanzmann publicó Shoah, el guion de su película homónima.
} 
de los prisioneros, su condición de "cadáveres en prórroga", como los describió Müller en Shoah (Lanzmann, 2003, p.75).

Encontramos en la película Dead Man (Jim Jarmusch, 1995) una analogía temática y técnica. Su protagonista, William Blake, interpretado por Johnny Depp, es igualmente descrito como un hombre que ya está muerto, otro "cadáver en prórroga" y, para retratar ese estado de enajenación previo a abandonar el mundo de los vivos, Jarmusch utiliza ese mismo recurso, enfocar al personaje y mantener fuera de foco todo lo que le rodea. La nitidez con la que el cine convencional se ha esforzado en mostrar el exterminio no se corresponde en absoluto con las palabras de los supervivientes, que evocan caos, desorden y pérdida de la voluntad debido al miedo y el agotamiento extremo. Por tanto, podemos asumir que, en esta nueva forma de pensar el pasado que propone Nemes -inspirándose en la obra de otros antes que él-, una verdad desenfocada que abre las puertas a la imaginación del espectador tiene más cabida que una mentira nítida.

\subsubsection{El color no maquilla, revela}

“Los prisioneros que han estado confinados durante un largo periodo de tiempo en la oscuridad adquieren tal susceptibilidad en la retina, que incluso en la oscuridad pueden distinguir objetos". (Goethe, [1840] 2015, p. 5). Se han extraído estas palabras de la Teoría de los Colores, publicada originalmente en 1810. La película que nos ocupa sumerge al espectador en el infierno de Auschwitz-Birkenau a través de los ojos de uno de los prisioneros. Así, se trata de mostrar el entorno tal y como era visto y sentido, experimentado, por los integrantes del Sonderkommando. Nemes procura que la lente de la cámara sea la retina del prisionero, algo en lo que el color va a jugar un rol esencial.

En esa idea de respetar y permanecer fiel al referente, no cabe impostar -el caso más paradigmático de hipertrofia cromática es el blanco y negro de La lista de Schindler, roto únicamente por la niña del abrigo rojo-, sino acudir a los colores más crudos, a una estética, por afán de poner etiquetas, más cercana al documental que a la ficción, o, en todo caso y sin ninguna duda, más cercana a la de Shoah que a la del filme de Spielberg. En palabras del cineasta Mátyás Erdély, director de fotografía y camarógrafo de El hijo de Saúl ${ }^{19}$ la intención era alejarse en todo momento de algo que fuera demasiado estético, fácil y agradable a la vista (Érdély, 2015). Ciertamente, ocurre con el etalonaje y la manipulación del color algo parecido a lo que ocurre con la música extradiegética. En el cine, ambos sirven para estetizar y hacer más llevadera la historia, para mantenerla sujeta a los parámetros del cine convencional. Y eso los dejaba automática y necesariamente fuera de El hijo de Saúl.

\subsubsection{El audio que no cesa}

En lo que respecta a los sonidos de una película, generalmente podemos destacar tres elementos. En primer lugar, los diálogos, el guión que los actores interpretan en un idioma concreto. En segundo, los sonidos ambiente, aquello que envuelve a los personajes. Ambos pertenecen a la diégesis, la realidad que se plantea en el filme. Por último, encontramos en la mayoría de

${ }^{19}$ Previamente, Erdély había trabajado en Türelem y, en 2018, repetiría con Nemes en Atardecer (Napszállta, László Nemes, 2018). 
las piezas una banda sonora que colorea las imágenes e incrementa su efecto, o que sirve como contraste del contenido visual. Se trataría en esta ocasión de música extradiegética, puro artificio con mero propósito estético. No es, pues, de extrañar que El hijo de Saúl carezca de banda sonora, o de cualquier sonido extradiegético que desentone con el contexto del campo. Por tanto, detengámonos en esos dos aspectos que sí forman parte de la narración. A lo largo del filme, van desfilando ante los oídos del espectador hasta un total de nueve lenguas -alemán, húngaro, polaco, yiddish, ruso, eslovaco, checo, griego y francés-, revelando así la naturaleza políglota de los campos. Interesa ese rechazo a uniformizar a través de una sola lengua -general e irónicamente el inglés- la diversidad intrínseca que encerraban aquellos lugares, algo que observamos en la mayoría de películas que han tratado el exterminio y que simboliza el peso de la industria cinematográfica del otro lado del Atlántico. En cuanto a los sonidos y ruidos que no cesan en ningún momento, cumplen una función parecida a la del fondo desenfocado, contribuyendo de esta forma a la desorientación de los personajes y del espectador. Acerca de esto, Nemes explica que todos los sonidos mecánicos y metálicos de la película se refieren al crematorio, que nunca dejaba de funcionar. En sus palabras, "es en cierta manera algo orgánico, una bestia que está viva" (citado en O'Sullivan, 2016, n.p.).

\section{La ética de la cámara es la estética de la película. Vida y muerte en El hijo de Saúl}

En su ensayo S'il y a de l'irreprésentable, Rancière (2001) mantiene que "irrepresentable" no es una propiedad intrínseca al Holocausto, y, por tanto, solo existen opciones (p. 96). De hecho, a lo largo de las páginas anteriores, no hemos hecho más que analizar y calibrar las distintas opciones que algunos cineastas consideraron acertadas a la hora de representar el exterminio étnico a manos de los nazis. Con todo, para Sánchez-Biosca (1999) las piezas concebidas, en especial las audiovisuales, siempre van a incluir ciertas cuestiones fundamentales que "no varían en absoluto: puesta en escena, relación presente/pasado, comportamiento ético de la memoria, articulación de lo vivido con la historia" y, la más importante y a la que dedicamos este artículo, "acoplamiento entre ética de la mirada y estética de la representación" (p.39). A través de nuestro estudio, hemos dado con piezas constituidas a base de opciones que consideramos adecuadas y otras que no lo son tanto, guiándonos en todo momento por ese tándem wittgensteniano que queda concretado en la ya mencionada proposición 6.421 del Tractatus a la que Sánchez-Biosca parece estar apuntando.

Carmona lo explica afirmando que "ética y estética fundamentan el mundo en tanto miradas, aproximaciones, configuraciones. Frente a la teoría ética, la vida ética" (2011, p. 213). Así, un acercamiento fílmico a un desastre de la categoría del Holocausto integrará una serie de decisiones estéticas - respecto a contenido, montaje, fotografía, etalonaje, etc.- tomadas por un cineasta que serán los parámetros empleados para calibrar el posicionamiento ético del producto final. Como hemos visto, las opciones por las que Spielberg se decantó para retratar el oscuro episodio pudieron responder más a propósitos y objetivos comerciales que a un genuino deseo de honrar a las víctimas y a los supervivientes. Rodó sobre el exterminio siguiendo las mismas reglas que había empleado para grabar el escurridizo sombrero de Indiana Jones en Indiana Jones en busca 
del arca perdida (Raiders of the Lost Ark, Steven Spielberg, 1981) o la bicicleta voladora de Elliot en E.T., el extraterrestre (E.T. the Extra-Terrestrial, Steven Spielberg, 1982). Frente a la estetización, banalización o monetización del Holocausto, estudiamos El hijo de Saúl como la concreción de una forma de hacer cine en general y de representar el genocidio en particular que responde a nuevas pautas ético-estéticas ${ }^{20}$. En esta línea, Breschand (2004) escribió que “las imágenes vampirizan nuestros sueños y nuestras certidumbres, al tiempo que los encarnan. Su exploración crítica es la condición necesaria para reactivar nuestros imaginarios, para nuestras formas de recorrer, y no ya de abarcar, el mundo". (p. 57)

Nemes y su equipo crearon un corpus de reglas exclusivo para la película y algunas de ellas, ya mencionadas, las podemos localizar fácilmente: no hay banda sonora ni sonido extradiegético alguno, el etalonaje aplicado a las imágenes nos recuerda a una estética más cercana al documental que a la ficción, la filmación en $35 \mathrm{~mm}$, que elimina la profundidad de campo casi en su totalidad... Así lo explicaba en una entrevista para El Mundo con motivo del estreno:

Nos obligamos a rodar de una manera muy determinada, con reglas muy estrictas. Cuando no estás limitado visual o estéticamente, el cine puede alcanzar niveles de sobreexposición hasta convertirlo todo en un simple espectáculo de entretenimiento. Al contrario, cuando limitas en campo visual y sólo permites que el espectador alcance a ver sólo fragmentos, consigues sugerir y haces sentir algo que, creo, está relacionado con la experiencia de un campo de exterminio. Con eso y con el espíritu mismo del cine (citado en Martínez, 2016, n.p.).

Se trata de una mirada "obligada a cruzarse con la muerte al pasar para rápidamente volver los ojos al suelo" (Didi-Huberman, 2015, p. 29). En El hijo de Saúl, la cámara nos recuerda que, para los prisioneros, cerrar los ojos no era una opción. El frenesí, los gritos, el alcohol, la violencia contra el resto de cautivos... describir Auschwitz es describir todo lo que las personas hacían para evitar encontrarse de frente con la muerte. Pero, como bien muestra Nemes, era inevitable.

\subsection{Historia de dos muertes}

El director húngaro evita la tentación de "fabricar" belleza a partir del sufrimiento, y nos muestra la muerte del niño desde esa estética documental tan característica de la película. Como apunta Reyes-Mate (2003), la grandeza del arte radica en no contarlo todo, "sino conducirnos mediante los expresado a lo inexpresable. Esa remisión a lo no expresado es lo que despoja a la belleza artística de la fatua pretensión de expresarlo todo" (p. 58). Un plano tembloroso en apariencia subjetivo - desde la perspectiva de Saúl-, esquinado, una mirada que atraviesa aberturas en muros de hormigón armado y se detiene en un grupo de hombres. Más allá de la inestabilidad que indica que la cámara no estaba montada sobre un trípode, sino a hombros de un operador, el plano es fijo, cercano a una pintura enmarcada (Imagen 5).

En la descripción recogida en el guion leemos que "los miembros del Sonderkommando que trabajan han disminuido ligeramente el ritmo, algunos parecen lanzar miradas furtivas a la escena"

\footnotetext{
${ }^{20}$ En lo que respecta a la representación de la barbarie y el trauma, hacemos una mención especial al ya fallecido cineasta Harun Farocki, que, con trabajos de corte más experimental como Images of the World and the Inscription of War (Farocki, 1989) o Respite (Farocki, 2007), también nos anima a desconfiar de la imagen, a ir más allá, a extraer interpretaciones y a llevar a cabo una suerte de "edición mental", en la que vamos completando los significados, siendo parte activa del proceso.
} 


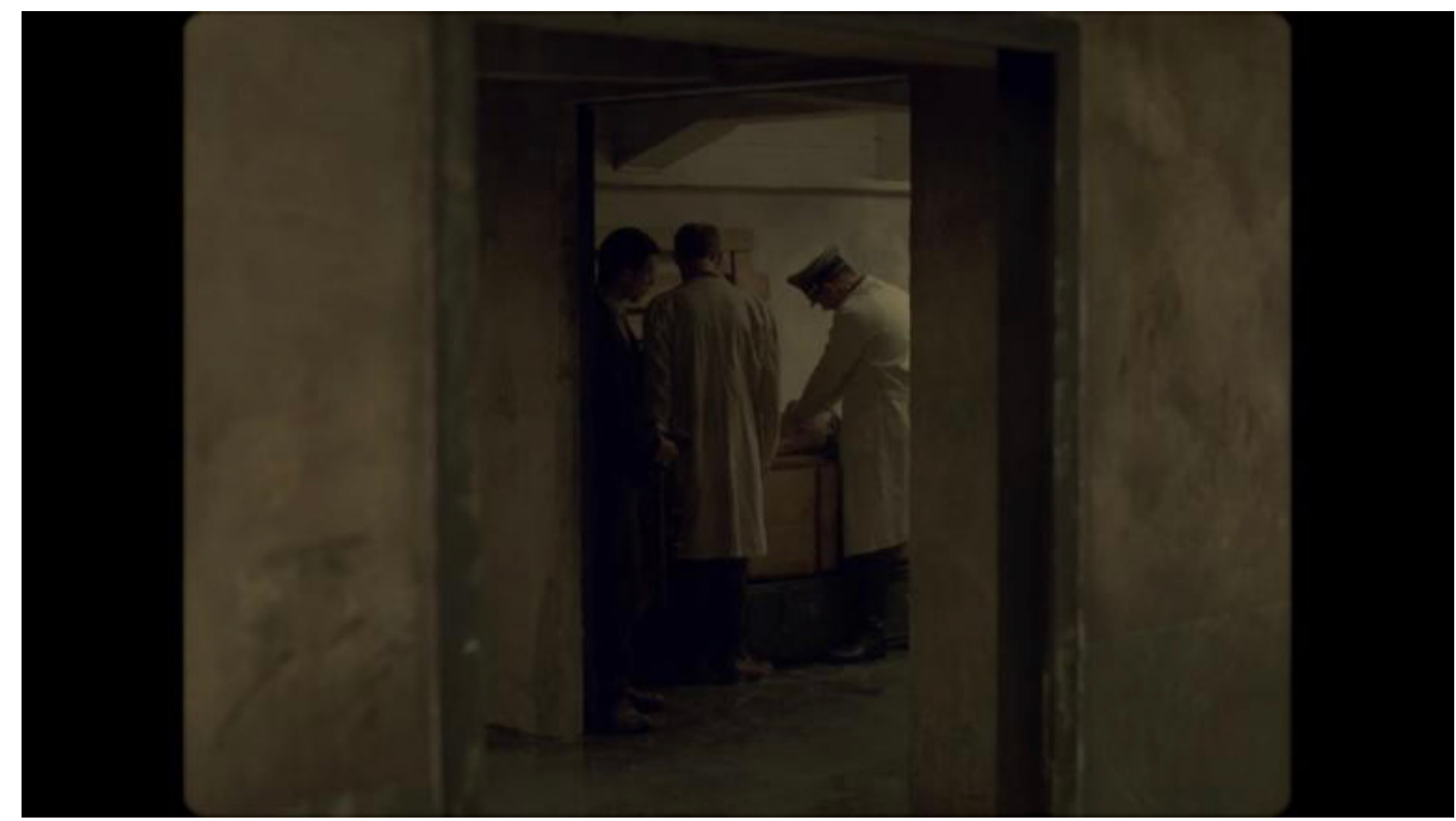

Imagen 5. Saúl mira la muerte de un niño

(Nemes y Royer, 2014, p. 6). La forma en que está dispuesto el plano resume el sigilo de los trabajadores que asisten a la tétrica escena, el sobrecogimiento que invade a Saúl mientras observa a ese supuesto hijo aún vivo, sin necesidad de florituras audiovisuales.

En el momento en que el médico alemán concluye la terrible tarea, comienza la trama. Apunta Marghitázi que es entonces cuando "el 'ver' sin intención de Saúl se transforma en "mirar", observando con verdadera atención, aunque normalmente intenta no ser consciente de lo que pasa a su alrededor" (Marghitázi, 2020, p. 88). La carrera frenética que empieza va a culminar con otra muerte, la del Saúl que sonríe, y con otra mirada furtiva, la del niño que descubre a los prisioneros fugados.

Ahora, los papeles se han intercambiado. Si al comienzo era Saúl el que miraba a un niño segundos antes de su muerte, ahora es al contrario (Imagen 6). Gracias a la similitud de ambos planos, reconocemos el principio y el fin de la historia de Saúl. Pero la identificación, que se produce exclusivamente a través de la puesta en escena y la disposición escalar del plano, es de una sutileza absoluta, sin un leitmotiv musical, ni un guion impostado. La muerte, que ha bailado a sus anchas durante toda la película en torno a Saúl, y, por tanto, en torno al foco de la cámara, poseyendo el plano y acosando tanto al espectador como al protagonista, se muestra tímida en esta última secuencia y se esconde. A juicio del premio Nobel húngaro Imre Kertész (1999), “habla a favor del gusto seguro y del estilo irreprochable de la película el hecho de que no veamos la muerte: pero los disparos de ametralladora que se oyen brevemente también poseen una función dramatúrgica y contienen un mensaje importante y aplastante" (p. 15).

Este elogio ético-estético se lo dedica Kertész a la secuencia final de La vida es bella, pero bien podría ir dirigido a los últimos minutos de El hijo de Saúl. Dice el húngaro que "el protagonista debe morir, y debe morir cómo y cuándo muere" (Kertész, 1999, p. 14). En el caso que nos ocupa, no hay mucho que podamos decir del "cómo" más allá de los disparos de ametralladoras que oí- 


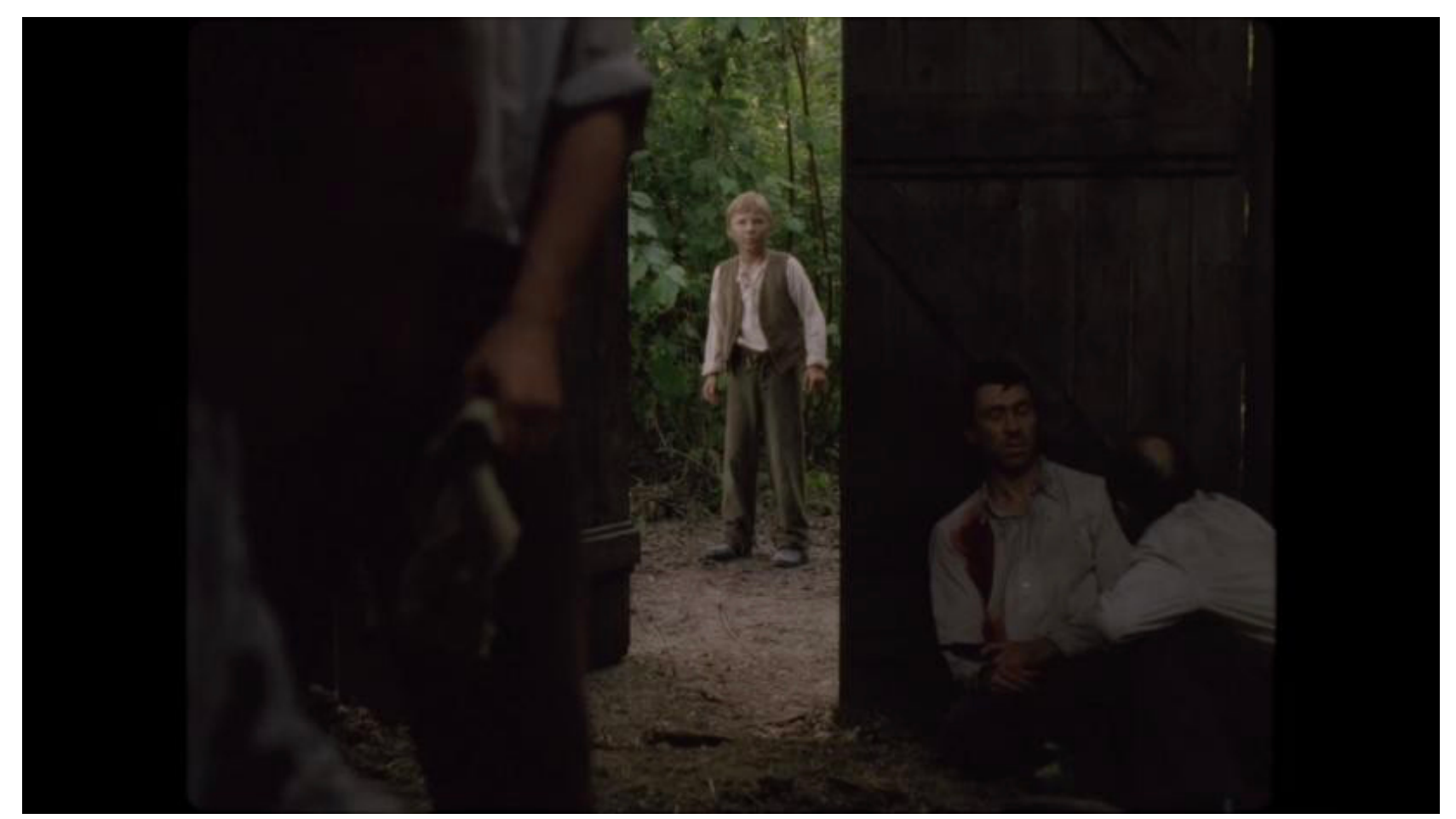

Imagen 6. Un niño anónimo mira la muerte de Saúl

mos en fuera de campo. Nemes decide no mostrar la muerte de Saúl. Una vez cumplido su cometido, la cámara se marcha con el niño, ese "portador de vida y de muerte" (Didi-Huberman, 2015, p. 49). Esta última secuencia nos recuerda a un fragmento del Diario de la galera (2004), donde Kertész expresa ese sentimiento de desarraigo del cuerpo, de abandono del plano material: “ $Y$ por fin, la sensación del retorno, por fin la liberación, por fin el plan: la génesis... Quiero hablar, confesar, contar la historia de la liberación de un alma o, mejor dicho, la historia de una gracia" (Kertész, 2004, p.62).

\section{Conclusiones}

El hijo de Saúl llegó setenta años después de la liberación de los campos para combatir la tendencia de simplificar el Holocausto e instrumentalizarlo y para despertar a un espectador adormilado, sacudiéndolo, suplicándole que no mirase hacia otro lado. Para elaborar este artículo, partíamos de la certeza de que las decisiones estéticas o formales adoptadas a la hora de contar cualquier historia sitúan tanto a quién las toma como a su producto - su película, su libro, su obra de arte...- en un lugar ético en el mundo. En esta línea, hablábamos del deber de los cineastas de mostrar éticamente, al igual que Wittgenstein nos recordaba que hemos de vivir y actuar éticamente. Siguiendo este razonamiento, una película sobre un acontecimiento tan extraordinariamente -en toda su carga etimológica- terrible como fue el Holocausto, no podría materializarse siguiendo las mismas reglas formales y estéticas que otra que verse sobre cualquier otro asunto. Sin embargo, a la hora de plasmar el exterminio nazi, la mayoría de cineastas han optado por lo cómodo, lo que no violenta, por ese canon hegemónico que inevitablemente degenera en clichés formales y semánticos. Frente a esto, interesa otro tipo de cine, uno cuyo proceso creativo, además, surja de una labor de documentación exhaustiva, lo que llevará necesariamente a la pregunta por el mostrar. A partir de ahí, el interés radica en interrogar al cine como medio, ahondar en sus recursos y experimentar con él, en lugar de intentar ajustar el relato al corsé de 
un fosilizado modo de representación institucional.

Por esto, creímos conveniente sintetizar las cuatro reglas -a las que se suma el montaje- que conforman el dogma al que se atuvieron férreamente los cineastas que concibieron El hijo de Saúl, y que nos remiten a la imagen, el foco, el audio y el color. El tratamiento tan particular de estos cuatro elementos cinematográficos hace de la película un producto cultural pensado, cuidado, como si de una pieza de artesanía se tratase. Además, nos detuvimos en esas tres metáforas tradicionalmente asociadas a la representación de la barbarie: la del martirio, la cinegética, y la infernal, tan fácilmente localizables en el filme. Estas fórmulas nos sitúan como espectadores en una constelación de visualidades comunes en torno al genocidio, pero verlas a través de los ojos de Saúl implica un reconocimiento, un momento donde lo nuevo confluye con lo recordado.

Porque es Saúl el encargado de articular la trama, de, sin quererlo, establecer una relación de empatía con el espectador a través de su misión suicida. Precisamente, su obsesión con dar sepultura al niño es lo único que lo diferencia del resto de prisioneros, además de la certeza de que su vida vale menos que la muerte del muchacho. Por esta razón nos detuvimos en la idea de la falsa excepcionalidad que se suele mostrar en las películas hegemónicas sobre el Holocausto. Nemes nos recuerda, por una parte, que, de no ser por su cometido, Saúl podría ser cualquiera, un hombre sin rostro, y por otra, que, en los campos, la muerte casi siempre ganaba el pulso a la vida. Por tanto, cabía preguntarse por el camino escogido por el director para concretar esa muerte que invadía el tiempo y el espacio en Auschwitz. Gracias al recurso del fuera de campo y a la mínima profundidad de campo, el cineasta propone al espectador ese ejercicio consistente en completar y decodificar el mensaje. En esa intuición, juega un papel esencial la memoria visual, la información que almacenamos acerca de los campos, y que Nemes manipula para rechazar lo explícito, esa estetización de la muerte. Así, se hace innecesario y hasta soezun plano detalle de una mano que cae inerte, o de un reguero de sangre convenientemente esparcido por el muro de un barracón.

Por otro lado, las dos muertes que vehiculan la película, la del niño al comienzo y la de Saúl al final, quedan perfectamente interconectadas a través de la disposición de los planos y el encuadre. Saúl empieza mirando el asesinato de un niño anónimo, y termina siendo mirado por otro niño sin nombre pocos segundos antes de morir. La cámara no permanece, sino que sigue al niño, que se aleja corriendo a través del bosque entre el sonido de disparos, único testimonio de la muerte de Saúl y sus compañeros huidos. Así, la primera muerte, que sí vemos, activa la trama, es un catalizador que acelera el mecanismo de esa segunda muerte del protagonista que había empezado mucho tiempo atrás.

Nemes rinde un respetuoso homenaje a la historia -los terribles acontecimientos que tuvieron lugar en Auschwitz en 1944- y al arte -el material que ya se había creado en torno al exterminio-, y lo hace a través de una ficción muy particular. Consideramos que los creadores, entre ellos los cineastas, deben poner en juego todo su ingenio a la hora de encontrar su sitio en el espectro de posibilidades que existen para representar el Holocausto. En última instancia, lo deseable sería que la complejidad del acontecimiento, en todas sus dimensiones, quedara recogida a través de la cámara y de la técnica consciente. Y, en ese retorcer los recursos que el cine ofrece, en ese constante interrogarse acerca de cómo traducir a estímulos audiovisuales lo que 
muchos han tachado de "inimaginable", podemos encontrar un comportamiento ético por parte del cineasta.

\section{Referencias bibliográficas}

Blottière, Mathilde (2015). Claude Lanzmann: “'Le Fils de Saul' est l'anti- 'Liste de Schindler'”. Télérama, 25 de mayo. Recuperado de https://www.telerama.fr/festival-de-cannes/2015/ claude-lanzmann-le-fils-de-saul-est-l-anti-liste-de-schindler,127045.php.

Blumenfeld, Samuel (2007). Rétrocontroverse: 1994, peut-on represénter la Shoah à l'écran? LeMonde, 8 de agosto. Recuperado de https://www.lemonde.fr/idees/ article/2007/08/08/retrocontroverse-1994-peut-on-representer-la-shoah-a-lecran_942872_3232.html.

Brecht, Bertolt (1998). Más de cien poemas. Madrid: Hiperión.

Breschand, Jean (2004). El documental: la otra cara del cine. Barcelona: Paidós.

Burucúa, José Emilio y Kwiatkowski, Nicolás (2015). "Cómo sucedieron estas cosas". Representar masacres y genocidios. Madrid: Katz Editores.

Carmona, Carla (2011). El genio: ética y estética son una. En M. J. Alcaraz, M. Carrasco y S. Rubio (Ed.), Art, Emotion and Value. Proceedings of the 5th Mediterranean Congress of Aesthetics (pp. 211-222). Cartagena (España). Recuperado de https://www.um.es/vmca/proceedings/ docs/VMCA-Proceedings.pdf.

Crespo, Alfonso (2008). Un cine febril. Herzog y El enigma de Kaspar Hauser. Sevilla: Metropolisiana.

Didi-Huberman, Georges ([2002] 2018). La imagen superviviente. Madrid: Abada Editores. Didi-Huberman, Georges (2004). Imágenes pese a todo. Barcelona: Paidós.

Didi-Huberman, Georges (2008). Cuando las imágenes toman posición. Madrid: Antonio Machado Libros.

Didi-Huberman, Georges (2015). Sortir du noir. Paris: Les éditions de minuit.

Erdély, Matyas (2015). En ARRI Channel [ARRIChannel] (27 de noviembre de 2015). ARRI Interview: Mátyás Erdély about "Son of Saul" [Archivo de vídeo]. YouTube. https://www.youtube.com/ watch?v=kTBKZUHsFbk\&t=379s.

Ferrando García, Pablo, y Gómez Tarín, Francisco Javier (2018). La inmersión subjetiva de un relato fenomenológico. A propósito de El hijo de Saúl (Saul fia, Lászlo Nemes, 2015). Fotocinema, 17, p. 297-320

Ginzburg, Carlo ([1976] 2001). El queso y los gusanos. Barcelona: Muchnik Editores. Godard, Jean-Luc (2007). Historia(s) del cine. Buenos Aires: Caja Negra. 
Goethe, Johann Wolfgang ([1810] 2015). Theory of colours. Londres: John Murray. Recuperado de http://www.gutenberg.org/files/50572/50572-h/50572-h.htm.

Gradowski, Zalmen (1988). The Czech Transport: A Chronicle of the Auschwitz Sonderkommando. En D. Roskies (Ed.), The Literature of Destruction: Jewish Responses to Catastrophe (pp. 548564). Harvard: Harvard University Press.

Kertész, Imre (1999). ¿A quién pertenece Auschwitz? Un superviviente del holocausto ante la película ‘La vida es bella'. Lateral: Revista de Cultura, 57, 14-15.

Kertész, Imre (2004). Diario de la galera. Barcelona: Acantilado.

Lanzmann, Claude ([1985] 2003). Shoah. Madrid: Arena.

Margitházi, Beja (2020). Embodying sense memory: archive image and traumatic experience in Son of Saul, Warsaw Uprising and Regina. Studies in Eastern European Cinema, 11(1), 82-100. Martínez, Luis (2016). ‘El hijo de Saúl': Miedo a mirar. El Mundo, 15 de enero.

Mate, Reyes (2003). Memoria de Auschwitz. Madrid : Trotta

Mayorga, Juan (2016). Elipses. Segovia : La Uña Rota.

Nemes, László (2015). En Alda, R. [6 de abril de 2019]. El cine de la 2 - El hijo de Saúl (presentación) [Archivo de vídeo]. RTVE.es. https://www.rtve.es/alacarta/videos/el-cine-dela-2/cine-2-hijo-saul-presentacion/5124261.

Nemes, László y Royer, Clara (2014). Son of Saul (guion). Recuperado de https://thescriptsavant. com/pdf/TheSonOfSaul.pdf.

O'Sullivan, Michael (2016). 'Son of Saul': an inmersive portrait of life in a Nazi death camp.

The Washington Post, 15 de enero. Recuperado de: https://www.washingtonpost. com/lifestyle/style/in-son-of-saul-an-immersive-portrait-of-life-in-a-nazi-deathcamp/2016/01/14/191e3c6e-b946-11e5-99f3-184bc379b12d_story.html

Pena, Jaime (2020). El cine después de Auschwitz. Madrid: Cátedra.

Rancière, Jacques. (2001). S'il y a de l'irreprésentable. Le genre humain, 36, 81-102.

Ridao, José María (2010). "Vivimos en un mundo que no sabe a dónde va”. El País, 18 de enero. Recuperado de: https://elpais.com/diario/2010/01/18/cultura/1263769201_850215.html

Rodríguez-Serrano, Aarón (2015). Espejos en Auschwitz. Apuntes sobre cine y Holocausto. Santander: Shangrila.

Sánchez-Biosca, Vicente (1991). Teoría del montaje cinematográfico. Valencia: Filmoteca de la Generalitat Valenciana.

Sánchez-Biosca, Vicente (1999). Hier ist kein warum. A propósito de la memoria y la imagen de los campos de la muerte. En A. Lozano (Ed.), La memoria de los campos. El cine y los campos de concentración nazis (pp. 13-38). Valencia: Ediciones de la Mirada.

Sánchez-Biosca, Vicente (2006). Cine de historia, cine de memoria. Madrid: Cátedra. 
Sardá, Juan (2012). Costa-Gavras: «Todo el cine es político». El Cultural, 30 de noviembre. Recuperado de: https://elcultural.com/Costa-Gavras-Todo-el-cine-es-politico Semprún, Jorge (2000). L'art contre l'oublie. Le monde des débats, mayo, 11-13. Unamuno, Miguel ([1913] 1976). Del sentimiento trágico de la vida. Madrid: Espasa-Calpe. Van Alphen, Ernst (1998). Caught by History: Holocaust Effects in Contemporary Art,Literature, and Theory. Stanford: Stanford University Press.

Wittgenstein, Ludwig ([1921] 1961). Tractatus Logico-Philosophicus. Madrid: Alianza.

Wittgenstein, Ludwig (1992). Lecciones y conversaciones sobre estética, psicología y creencia religiosa. Barcelona: Paidós.

Zizek, Slavoj (2009). Description without a place. On Holocaust and Art. Inaesthetik: Politics of Art, 1,142-161. 